\title{
Development of Kinetic Friction Coefficient Experiment Tools Based on Arduino Nano ATmega 328P LDR Sensor
}

\author{
Candra Dewi ${ }^{1}$, Millati Azka ${ }^{2}$, Hartono $^{2}$, Supriyadi ${ }^{2}$ \\ \{candradewi875@gmail.com; millatilila@yahoo.co.id; hartono@mail.unnes.ac.id; \\ supriyadi@mail.unnes.ac.id\} \\ SMK Texmaco Semarang; Jalan Raya Mangkang, Km 16, Kota Semarang ${ }^{1}$ \\ Graduate School, Universitas Negeri Semarang; Jalan Kelud Utara III, Kota Semarang, Indonesia ${ }^{1,2}$
}

\begin{abstract}
Learning-based industrial revolution 4.0 is focused on improving digital skills, one of which is by using of Arduino-based microcontrollers. This study aims to develop a digital kinetic friction coefficient by using Arduino Nano ATmega 328P with LDR sensors. Type of the research is research and development $(\mathrm{RnD})$, the stages are includes defining, designing, developing and disseminating. Based on the results of the test tool, it was found that the kinetic friction coefficient for mass and angle variations for the fabric, towel, and carpet fields showed consistently. The kinetic friction coefficient between the object and the surface of the fabric type is 0.6053 ; the towel field type is 0.5733 ; the carpet type is 0.4199 . Thus, practicum tools that have been developed can be used to determine the kinetic friction coefficient between the object and the surface.
\end{abstract}

Keywords: Arduino Nano, LDR sensor, kinetic friction coefficient.

\section{Introduction}

Learning-based industrial revolution 4.0 demands a various skills. It can be achieved the students through technology approach and digital system. This approach aims to change the pattern of life and human interaction which is characterized by an increase in the digitalization of manufacturing. Lee [1] stated that there are four factors can influence manifacture digitalize, one of them is there is a new collaboration between humans and machine.

The skills related to interaction with humans with machines in physics learning can be done through laboratory activities. It is a special room to conduct practicum in science learning and it requires some special tools that can not be presented in class [2]. In this activity, students will learn to use tools, try to take data, analyze, and make conclusions. According to Kemendikbud [3] scientific learning through practicum can improve the students' skills especially in formulating problems, proposing and testing hypotheses, determining variables, designing and conducting experiments, collecting and processing data, making conclusions, and communication. It is supported by Hartono [4], he also added that students' scientific process skills improve through practical activities since in practical activities students are given the opportunity to carry out process activities directly.

The results of laboratory observations and interviews of Semarang State High School 2 physics teachers obtained the practice of physics for classes X, XI, and XII classified as frequent, but all were done in a simple, simple and manually operated way. In the physics 
laboratory of Semarang State High School 2, also has a digital practicum, but these tools do not get good treatment so it is damaged and cannot be used. Based on information from the physics teacher that the students who did the practicum, but did not know the purpose, benefits, and practicum concept. Students only receive teacher orders and cannot understand well.

The coefficient of the friction is a physics concept in which students often experience calculated difficulties and related phenomena [5]. Determination coefficient of the friction can be done in three ways, namely by using a beam drawn with a pulley on a flat plane, the beam that slides on the inclined plane, and the beam-drawn with a pulley in the inclined plane [6]. In the development of this tool, the coefficient of friction is determined from the beam that glides on the inclined plane. Through the inclined plane, it will be seen physically if the type of the friction plane increasingly rough, so the time beam to arrive at the base plane will also be longer.

This study aims to develop a digital practicum coefficient of the kinetic friction. This tool is equipped with Arduino Nano 328P as an automatic timing counter tool. The digital tool is developed that do not need maintenance and technical assistance to find out the benefits of practicum. Besides, there are digital practicum tools that can train students to be closer to digitizing technology.

\section{Methods}

The type of research is Research and Development $(\mathrm{RnD})$. This research was conducted at the Physics Workshop Laboratory of FMIPA Unnes, Sekaran, D9 1st floor. The design of this study used the 4-D (Four D Models) proposed by Thiagarajani. The research steps are defining, designing, developing and disseminating (disseminate).

In the defining stage is an analyses needs of the students in discussing a deeper physical concept. After that, the selection of the specific objectives in the development of the tool. At the designing stage, start to do the selection of tool design, the selection of tools and materials, the end makes the design of the tool. At the developing stage are data testing and trials the tools. After several tests were carried out before being disseminated, the practicum tool was repaired. Data collection technique are validation tests by trial and error.

Tools and materials used in the development of this tool include Arduino Nano-based ATmega 328 microcontroller, liquid crystal display (LCD), I2C LCD backpack module, light detection sensor module with LDR, Surface Mout Device, acrylic as the base material sloping, plywood given a variety of types of surfaces, fabrics, towels, carpets, objects, bows, and rulers.

\section{Results and Discussion}

\subsection{Development of Practicum Tools}

The development of an Arduino Nano ATmega 328P based practical instrument is to minimize student errors in calculating the travel time for objects. Also, this tool can provide stimulus and motivation for students to develop sensors that can improve aspects of technological literacy. This is related to the learning process of industrial revolution 4.0 which 
focuses more on increasing digital literacy, technology literacy, and human literacy [7]. The results of the development kinetic friction coefficient practicum tool can be seen in Figure 1.

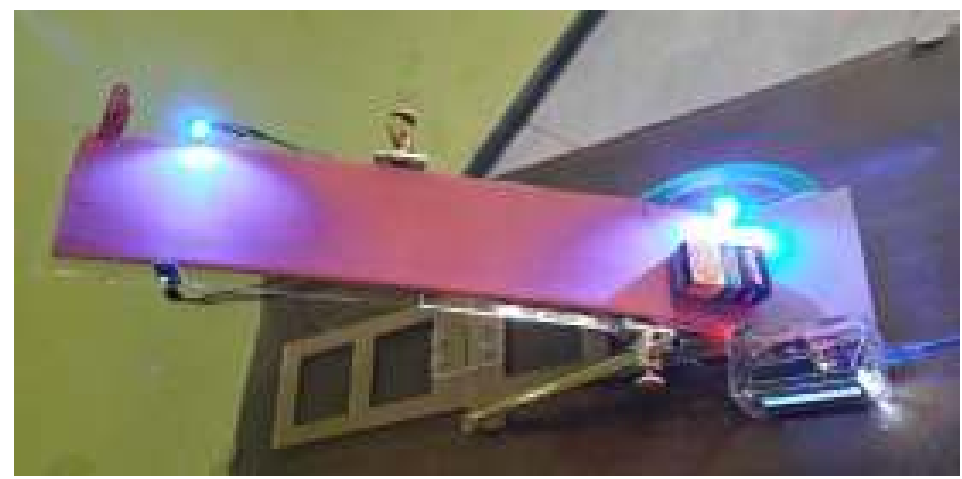

Figure 1. Practicum Tools

The working principle of the tool is when the object is at point A, the LED is closed by the object and the LDR sensor starts working (counting time) when no light is captured. When the object reaches point $\mathrm{B}$, the LED is closed by the object and the LDR sensor does not get light, the timer stops counting time, so it takes into account the travel time from point A to point B. The LED used is a type of Surface Mount Device with faster complexity so that when practicing inside or outside the room, the ambient light does not affect the LDR sensor.

\subsection{Trial of the Practical Tool}

This research is carried out by launching objects from the top of the inclined plane that has been given a certain friction plane. There are three types of friction fields used, wood coated with fabric, towel, and carpet. In each friction field, a trial was conducted with two variations, variations in object mass and slope angles. In variations in mass, the slope angle of the field is made constant that is $\theta^{0}=50$ and in angular variations, the object mass is constant which is $0.006 \mathrm{~kg}$.

The magnitude of the kinetic friction coefficient between objects and slides is determined by analyzing the motion of the objects in the inclined plane by using the Newton II law. The equation (1) to determine the kinetic friction coefficient between the surface of the object and the friction plane as follows.

$$
\mu_{k}=\tan \theta-\frac{h}{g t^{2} \sin \theta \cos \theta}
$$

The results of the trial on variations in mass are presented in Table 2. 
Table 2. Trial Test Results Data on Mass Variations

\begin{tabular}{cccccc}
\hline No & $\begin{array}{c}\text { Friction field } \\
\text { type }\end{array}$ & Mass (kg) & Time(s) & $\begin{array}{c}\text { Kinetic friction } \\
\text { coefficient, } \boldsymbol{\mu}_{\boldsymbol{k}}\end{array}$ & $\overline{\boldsymbol{\mu}_{\boldsymbol{k}}}$ \\
\hline \multirow{3}{*}{1} & & 0.001 & 0.37 & 0.6922 & \\
& FABRIC & 0.006 & 0.33 & 0.5638 & 0.6280 \\
& & 0.011 & 0.33 & 0.5638 & \\
& & 0.021 & 0.37 & 0.6922 & \\
& & 0.001 & 0.33 & 0.5638 & \\
& \multirow{2}{*}{ TOWEL } & 0.006 & 0.33 & 0.5638 & 0.5638 \\
& & 0.011 & 0.33 & 0.5638 & \\
& & 0.021 & 0.33 & 0.5638 & \\
3 & \multirow{3}{*}{ CARPET } & 0.001 & 0.31 & 0.4801 & \\
& & 0.006 & 0.29 & 0.3786 & 0.4039 \\
& & 0.011 & 0.29 & 0.3786 & \\
\hline
\end{tabular}

Based on the results in Table 2, it was found that with variations in the value of the mass that glide on the inclined plane, it does not produce different times. The time it takes for objects to move from the top of the inclined plane to the bottom of the inclined plane is almost even the same for different mass values. This happens because the type of the object used is the same that is a beam made of paper. Mass variation is done by adding mass in the beam.

The results of the trial data in angular variations on Table 3 show that the kinetic friction coefficient in one type of friction field is not much different. This means that the kinetic friction coefficient is not influenced by the time and slope of the field, because the kinetic friction coefficient is constant. The time and slope angle of the field are only physical quantities to help calculate the kinetic friction coefficient value. The coefficient of friction is not only influenced by the material from the contact surface and the presence or absence of solid or liquid matter separating the contact surface; also varies with the use of different measuring equipment, the coefficient of friction must be measured by the size of the corresponding device surge, as noted [8].

Table 3. Test Results Data on Angular Variations

\begin{tabular}{|c|c|c|c|c|c|}
\hline No & $\begin{array}{c}\text { Friction Field } \\
\text { Type }\end{array}$ & Angular ( $\left.{ }^{0}\right)$ & Time (s) & $\begin{array}{l}\text { Kinetic friction } \\
\text { coefficient, } \mu_{k}\end{array}$ & $\overline{\mu_{k}}$ \\
\hline \multirow{6}{*}{1} & \multirow{6}{*}{ FABRIC } & 30 & 1.47 & 0.5555 & \multirow{6}{*}{0.5826} \\
\hline & & 35 & 0.77 & 0.6149 & \\
\hline & & 40 & 0.51 & 0.6279 & \\
\hline & & 45 & 0.38 & 0.5831 & \\
\hline & & 50 & 0.33 & 0.5638 & \\
\hline & & 55 & 0.29 & 0.5501 & \\
\hline \multirow{6}{*}{2} & \multirow{6}{*}{ TOWEL } & 30 & 0.96 & 0.5262 & \multirow{6}{*}{0.5827} \\
\hline & & 35 & 0.70 & 0.5969 & \\
\hline & & 40 & 0.48 & 0.6008 & \\
\hline & & 45 & 0.39 & 0.6042 & \\
\hline & & 50 & 0.34 & 0.6181 & \\
\hline & & 55 & 0.29 & 0.5501 & \\
\hline \multirow{6}{*}{3} & \multirow{6}{*}{ CARPET } & 30 & 0.63 & 0.4390 & \multirow{6}{*}{0.4359} \\
\hline & & 35 & 0.48 & 0.4806 & \\
\hline & & 40 & 0.39 & 0.4781 & \\
\hline & & 45 & 0.34 & 0.4792 & \\
\hline & & 50 & 0.29 & 0.4032 & \\
\hline & & 55 & 0.26 & 0.3358 & \\
\hline
\end{tabular}


The results of the trials in Table 3 also show that the more sloping a field, so the more time needed to be faster or shorter. Thus it is said that the difference in the slope of a field greatly influences the motion time of an object. In increasingly rough conditions, the kinetic friction coefficient is also greater. Therefore, objects will increasingly reach the base of the field which means that the speed of small objects. This is supported by the results of a study by Shih \& Sung [9] that the minimum kinetic friction coefficient value occurs when the speed of the object gliding in the friction plane is large. This condition occurs in a finer area of friction that is given lubricant. Moran's research [10] also states that the coefficient of friction occurs between two contact surfaces with relative motion, the faster the speed between two contact surfaces is the smaller the coefficient of friction.

The other experimental results of computer program analysis conducted by Spinu \& Cerlinca [11] show that the friction coefficient os an invariant regardless of the normal load and the surface roughness. The coefficient of friction between one object and another is varied and is influenced by the level of surface roughness. The coefficient of friction decreases with increasing normal force and roughness.

The value of the kinetic friction coefficient appears as a result of the interaction of two surface objects so that depends on the type of object and type of friction field. Therefore, if the object in this experiment is replaced by another object, it will certainly give a different kinetic friction coefficient value. In the research and development of this tool, it was found that the coefficient of friction between objects with carpet carpets has the smallest value. This is because the contact force between objects and carpet is reduced due to the effect of carpet texture [12].

The practicum tool for kinetic coefficient based on Arduino Nano 328P with LDR sensor can be used to determine the kinetic friction coefficient between an object and the friction plane. Practicum that is using this tool can minimize student errors when recording the time the object is released from top to field. Through the development of this tool, it is expected to motivate students to develop other digital technologies using Arduino.

\section{Conclusion}

Based on the research and development of the practicum tools, we can conclude that these tools can to be used in physics learning on the friction topic. Achievement of the concept is shown from the results of the tool trials. At large slopes, the object will slide faster so the time needed too short to until the bottom fields. The rougher of the surface, the kinetic friction coefficient gets bigger so the object too long to until the bottom fields mean that the speed of the object is small. Coefficient of the friction between the object and surface field for the same object will get the same value. Other results show that carpet trajectories have a smaller coefficient of the friction than fabric or towel. This means that the style of the interaction between the surface of the object and carpet is very small because they do not pressure each other. 


\section{References}

[1] Lee, J., Lapira, E., Bagheri, B., \& Kao, H.: Recent advances and trends in predictive manufacturing systems in the big data environment. Manuf. Lett. Vol. 1, pp. 38-41 (2013).

[2] Supriyadi \& Sulhadi.: Modul pengelolaan laboratorium fisika. Program Pascasarjana Unnes, Semarang (2013).

[3] Kemendikbud.: Silabus mata pelajaran sekolah menengah atas/ madrasah aliyah mata pelajaran fisika. Kementrian Pendidikan dan Kebudayaan, Jakarta (2016).

[4] Hartono \& Oktafianto, A. R.: Keefektifam pembelajaran praktikum ipa berbantuan LKS discovery learning untuk mengembangkan keterampilan proses sains. Unnes Physics Education Journal. Vol. 3, pp. $16-22$ (2014).

[5] Onorato, P., Mascoli, D. \& Ambrosis, A. D.: Damped oscillations and equilibrium in a massspring system subject to sliding friction forces: integrating experimental and theoretical analyses am. J. Phys. 781120 (2010).

[6] Serway, R. A. \& Jewett, J. W. (2009). Physics for scientists and engineers, 7th edition. California: Thomson Brook/ Cole.

[7] Aoun, J. E.: Robot-proof: higher education in the age of artificial intelligence. MIT Press, US (2017).

[8] Chang, W.-R., Kim, I.-J., Manning, D. P. \& Bunterngchit, Y. The role of surface roughness in the measurement of slip-periness. Ergonomics. Vol. 44, pp. $1200-1216$ (2010).

[9] Shih, M.-Hs. \& Sung, W.-P.: Developng smart measurement device to measure kinetic friction coefficients of bi-tilt isolator. Hindawi Advances in Civil Engineering, https://doi.org/10.1155/2019/4392506 (2019).

[10] Moran, J. \& Sucharitakul, T.: Variations in dry sliding friction coefficients with velocity, recent advances on mechanics, materials, mechanical engineering and chemical engineering. Proceedings of International Conference on Mechanics, Materials, Mechanical Engineering and Chemical Engineering, Spain. pp. 181-194 (2015).

[11] Spinu, S. \& Cerlinca, D.: Prediction of static friction coefficient in rough contacts based on the junction growth theory. IOP Conference Science: Materials Science and Engineering. 227012119 (2017).

[12] Fuadi, Z., Zahouani, H., Takagi, T., \& Miki, H.: Effect of roughness on stiction. IOP Conference Series: Materials Science and Engineering. 352012009 (2018). 